\title{
The effect of fly ash and granulated blast- furnace slag on slip and tensile adhesion strength of tile adhesives mortars
}

\author{
Michat Wieczorek ${ }^{1, *}$ \\ ${ }^{1}$ Sieć Badawcza Łukasiewicz - Instytut Ceramiki i Materiałów Budowlanych, Oddział Szkła I \\ Materiałów Budowlanych w Krakowie
}

\begin{abstract}
In the formulations of adhesive mortars for tiles almost exclusively CEM I Portland cements are used. Practically no CEM II CEM V cements with additives are used, although they are often produced with strength classes $32.5 \mathrm{R}$ and some even 42.5R. Relationship between strengths of tile adhesives in which cement was partially replaced with fly ash and granulated blast furnace slag was studied. A fly ash was used in three different replacement levels from $5 \%$ to $25 \%$ by weight of either cement. The tensile adhesion were determined at 28 and 90 days after various conditioning conditions of the samples. The influence on the flexibility of mortars was also assessed. In small substitution levels, fly ash replacement increased the tensile adhesion strength. The results indicate that the optimal amount of fly ash and granulated blast furnace slag additive replacing a given amount of cement allows to obtain adhesive mortars for tiles with high functional parameters.
\end{abstract}

\section{Introduction}

Cement-based adhesive mortars are designed to fix tiles or insulation materials to various surfaces, mainly concrete. Depending on the construction technology, the substrate, the element to be attached, the performance criteria as well as the standards and regulations for testing adhesives and, above all, the binder type, the properties of adhesive mortars may vary. Is is also reflected by growing requirements in terms of adhesive performance such as fast strength gain over time, high adhesion and flexibility for large-tile installations or on the so-called critical substrates.

The requirements for powder adhesives are defined in EN 12004 [1] and in the guidelines for granting technical assessments.

The basic requirement for cement adhesives is the adhesion under the conditions that reflect the actual conditions of use of the adhesive. This is of great importance for the overall durability of the system in the configuration: substrate - mortar - bonded element. Adhesion includes physical and chemical processes that take place during bonding/attachment of one element to another. The system is affected by a number of factors such as water absorption, amount and composition of cement, amount and type of

*Corresponding author: m.wieczorek@icimb.pl 
polymer used as a cement modifier, the way the adhesive is applied, water to cement ratio and other factors.

Cement is the basic binder when it comes to adhesive formulas. In the formulas cement content usually varies between $30-40 \%$ of adhesive weight. Portland clinker-based cements make a wide range of products covered by the standard EN 197-1 [2]. In adhesive formulas there are almost solely used rapid setting Portland cements CEM I 32,5R; CEM I 42,5R and CEM I 52,5R. Practically no CEM II - CEM V cements with admixtures are used, although they are often of strength class $32.5 \mathrm{R}$ and some even $42.5 \mathrm{R}$.

The cement industry is particularly affected by the growing environmental requirements, which mainly relate to the reduction of dust and greenhouse gas emissions, mainly $\mathrm{CO}_{2}$. Portland cement clinker production technology is one with the highest emission. As provided in the literature, the production of 1 ton of Portland clinker (making up to $95 \%$ of the weight of Portland cement CEM I) requires the consumption of about 1.7 tons of natural resources and is responsible for the emission of about $800 \div 900 \mathrm{~kg}$ of $\mathrm{CO}_{2}$. Reductions in those emissions are possible through changes in the cement manufacturing process [3]. They include the production of multi-component or composite cements with a large amount of mineral admixtures and the modification of the cement clinker production process by changing the blend and using biomass-rich alternative fuels.

A significant reduction of $\mathrm{CO}_{2}$ emission per unit of a final product i.e. cement has been obtained in recent years by the increasing scale of the production of composite cements CEM II $\div$ CEM V with a high content of main components other than Portland clinker. The use of cements with a low content of Portland clinker allows for ecological reasons as well as technological and economic considerations. The use of mineral additives with proven latent hydraulic properties for blast furnace slag and for silica fly ash with pozzolanic properties, brings many benefits. They are related to the modification of setting time as well as dynamics of strength development, porosity, shrinkage resistance and the resistance to chemical aggression of both fresh mixture and hardened mortar. It is also possible to achieve much higher strength, especially after longer curing periods. This issue has been studied by a number of researchers [4-8]. The use of more than one mineral additive allows to combine the properties of main cement components i.e. to achieve the synergy effect and to ensure the effective control of the hardening process and to obtain cements of compelling performance [9]. The consideration of the ecological issue combined with continuous striving for improvement of cements by adding or enhancing some useful properties, are conducive to further development of an assortment of cements. New types of composite cements are subject to intensive standardisation efforts leading to an amendment of the current cement standard (EN 197-1) [10]. So far, little research has been done on the use of such cements in cement-based powder adhesives. Such adhesives have to meet a number of requirements for their strenth and performance such as fast strength gain over time, high adhesion and flexibility. Therefore, the aim of the study was to conduct preliminary research, including an assessment of the possibility of use of granulated blast furnace slag and silica fly ash, as a basis for discussion on reducing the clinker content of cements used in powder adhesives.

\section{Specimens}

For the experimental tests, Portland cement CEM I 42.5R compliant with EN 197-1 was used and its characteristics are presented in Tables 1 - 2. Fly ash compliant with the EN 450-1 [11] standard, obtained for the tests from the combustion of hard coal in conventional boilers from three national power plants, was used to carry out the tests.

The following ash specimens were used:

- Ash 1 - silica fly ash not activated 
- Ash 2 - silica fly ash activated by grinding in a ball mill

- Ash 3 - silica fly ash activated in a fluidized bed dryer

Table 1. Physical properties of cement

\begin{tabular}{|c|c|c|c|}
\hline \multicolumn{2}{|c|}{ Property } & $\begin{array}{c}\text { Test method } / \\
\text { standard }\end{array}$ & Test result \\
\hline \multicolumn{2}{|c|}{ Compressive strength [MPa] } & PN-EN 196-1 & 57,0 \\
\hline \multirow{2}{*}{$\begin{array}{c}\text { Setting time } \\
\text { [min.] }\end{array}$} & initial & PN-EN 196-3 & 170 \\
\cline { 2 - 4 } & final & PN-EN 196-3 & 210 \\
\hline \multicolumn{2}{|c|}{ Water demand [\%] } & PN-EN 196-3 & 28,4 \\
\hline \multicolumn{2}{|c|}{ Volume expansion $[\mathrm{mm}]$} & PN-EN 196-3 & 0,5 \\
\hline \multicolumn{2}{|c|}{ Blaine specific surface $\left[\mathrm{cm}^{/ 2} / \mathrm{g}\right]$} & PN-EN 196-3 & 3970 \\
\hline
\end{tabular}

Table 2. Phase composition of cement

\begin{tabular}{|l|c|}
\hline \multicolumn{1}{|c|}{ Conposition } & \% mass \\
\hline Alite & 68,3 \\
\hline Belite & 3,7 \\
\hline Aluminate & 5,6 \\
\hline Ferrite & 9,0 \\
\hline Free lime & 0,5 \\
\hline Portlandite & 0,0 \\
\hline Periclase & 0,4 \\
\hline Arcanit & 1,2 \\
\hline Gipum & 2,6 \\
\hline Bassanite & 2,2 \\
\hline Anhydrite & 0,5 \\
\hline Calcite & 5,7 \\
\hline Quartz & 0,3 \\
\hline
\end{tabular}

Moreover, 2 samples of blast furnace slag, differing in hydraulic activity index, were taken for testing. Selected physical properties of fly ash and slag are presented in Tables 3 and 4.

Table 3. Properties of granulated blast furnace slag used

\begin{tabular}{|c|c|c|}
\hline \multirow{2}{*}{ Property } & \multicolumn{2}{|c|}{ Test result } \\
\cline { 2 - 3 } & Slag 1 & Slag 2 \\
\hline Glass phase content [\%] & 98 & 85 \\
\hline Activity index [\%]: & & \\
- 7-day & 72,4 & 107,9 \\
- 28-day & 62,9 & 96,8 \\
\hline
\end{tabular}


Table 4. Properties of fly ash used

\begin{tabular}{|c|c|c|c|}
\hline \multirow{2}{*}{ Property } & \multicolumn{3}{|c|}{ Test result } \\
\cline { 2 - 4 } & Fly ash 1 & Fly ash 2 & Fly ash 3 \\
\hline Fineness, [\% masy] & 22,0 & 38,9 & 35,3 \\
\hline Bulk density, [kg/m ] & 2054 & 2250 & 2250 \\
\hline Pozzolanic activity index [\%]: & & & \\
- 28-day & 79,8 & 80,0 & 86,9 \\
- 90-day & 87,3 & 88,0 & 94,2 \\
\hline Initial time [min.]: & & & 205 \\
- from reference cement & 210 & 200 & 280 \\
- 25\% fly ash and 75\% reference & & & 111,0 \\
\hline cement & 345 & 285 & \\
\hline Water demand [\%] & 104,2 & 115,3 & 1 \\
\hline
\end{tabular}

Additionally, quartz sand with a grain size between 0.1-0.5 mm and a re-dispersible powder of polyvinyl acetate and methylcellulose were used to prepare tile powder adhesives. Polymer-based admixes amounted to about $1 \%$ of cement weight. To achieve a stabilized setting time calcium formate was added in the amount of $0.5 \%$ of the weight of the mixture.

\section{Testing method}

In the tests, cementitious tile adhesive without ash or slag admix was taken as a reference mixture (R). A series of 9 mixtures was prepared by replacing cement with $10 \%, 20 \%$ and $25 \%$ fly ashes (formulation A, B and C respectively) and 2 mixtures with an addition of granulated blast furnace slag as shown in Table 6 at $20 \%$ substitution level. The above clinker substitution levels corresponds to the commonly used CEM II cements. Mixtures were prepared in a laboratory by mixing the components for a constant mixing time of 10 minutes that ensures proper sample homogenisation. For the prepared adhesives, the w/b ratio was determined to add the proper amount of water and obtain the consistency ensuring a cone penetration in the prepared adhesive to the depth of $8.5 \mathrm{~cm}$ during the test, carried out according to the PN-85/B-04500 standard [12]. The binder cure time before final mixing was 10 minutes. In accordance with EN 1348:2008 [13] concrete slabs and ceramic tiles were used as a substrate. Next, the standard properties of the 11 prepared adhesives were tested using the methods specified in the relevant EN 12004 standard. Tensile strength was determined in accordance with EN 1348:2008 [13] and included:

- initial adhesion (point 8.2 of the above standard) for samples stored for 28 and 90 days,

- adhesion after immersion in water (point 8.3) for samples stored for 28 and 90 days,

- adhesion after heat treatment (point 8.4) for samples stored for 28 and 90 days.

Intercoat adhesion of the system: concrete substrate - tested adhesive - ceramic tile was tested using the pull-off test. Moreover, a slip test was carried out according to EN 1308 [14]. 
Table 5. Composition of tested adhesive mortars [\%]

\begin{tabular}{|c|c|c|c|c|c|c|c|}
\hline & & $\mathbf{R}$ & 1 & 2 & 3 & 5 & 6 \\
\hline \multirow{3}{*}{$\begin{array}{c}\text { CEM I } 42,5 \\
\text { R }\end{array}$} & $\mathrm{A}$ & \multirow{3}{*}{40} & 36 & 36 & 36 & \multirow{3}{*}{-} & \multirow{3}{*}{-} \\
\hline & $\mathrm{B}$ & & 32 & 32 & 32 & & \\
\hline & $\mathrm{C}$ & & 30 & 30 & 30 & & \\
\hline \multirow{3}{*}{ Fly ash 1} & $\mathrm{~A}$ & \multirow{3}{*}{-} & 4 & - & - & \multirow{3}{*}{-} & \multirow{3}{*}{-} \\
\hline & $\mathrm{B}$ & & 8 & - & - & & \\
\hline & $\mathrm{C}$ & & 10 & - & - & & \\
\hline \multirow{3}{*}{ Fly ash 2} & $\mathrm{~A}$ & \multirow{3}{*}{ - } & - & 4 & - & \multirow{3}{*}{-} & \multirow{3}{*}{ - } \\
\hline & $\mathrm{B}$ & & - & 8 & - & & \\
\hline & $\mathrm{C}$ & & - & 10 & - & & \\
\hline \multirow{3}{*}{ Fly ash 3} & $\mathrm{~A}$ & \multirow{3}{*}{ - } & - & - & 4 & \multirow{3}{*}{-} & \multirow{3}{*}{-} \\
\hline & $\mathrm{B}$ & & - & - & 8 & & \\
\hline & $\mathrm{C}$ & & - & - & 10 & & \\
\hline \multicolumn{2}{|l|}{ Slag 1} & - & - & - & - & 8 & - \\
\hline \multicolumn{2}{|l|}{ Slag 2} & - & - & - & - & - & 8 \\
\hline \multicolumn{2}{|c|}{ Quarz sand } & 55 & 55 & 55 & 55 & 55 & 55 \\
\hline \multicolumn{2}{|c|}{$\begin{array}{c}\text { Modifying } \\
\text { additives }\end{array}$} & 5 & 5 & 5 & 5 & 5 & 5 \\
\hline
\end{tabular}

As specified in the standard, the specimens were stored at the relative humidity of $50 \pm$ $5 \%$ and the temperature of $23 \pm 2{ }^{\circ} \mathrm{C}$ and, depending on the type of determination, additionally exposed to water or the temperature of $70^{\circ} \mathrm{C}$. To determine their strength after 90 days, the specimens were stored at $50 \pm 5 \%$ relative humidity and the temperature of 23 $\pm 2{ }^{\circ} \mathrm{C}$ after the conditioning as specified in the standard. During the analysis of the test outcomes (10 for each determination) any values that deviated from the mean value by more than $20 \%$ were rejected.

\section{Results and discussion}

The results of initial adhesion are presented in Figures 1-4. The results show that a $10 \%$ and $20 \%$ admixture slightly affected the initial adhesion after both 28 and 90 days. The differences between the results for adhesives with ash or slag admix and the reference adhesive do not exceed the measurement error that, for the values obtained, may be up to $20 \%$.

It should be emphasised that all the mortars have an initial adhesion of $\geq 1.0 \mathrm{MPa}$, allowing the basic standard requirement of $\geq 0.5 \mathrm{MPa}$, i.e. for mortars with enhanced strength parameters, to be met by a margin. The $25 \%$ admixture of ash 1 resulted in a more noticeable modification of the initial adhesion, reducing it to $36 \%$ of the initial value for both sample conditioning times. The decreases in adhesion were smaller for slag admixture than for ash and they did not exceed $20 \%$. 


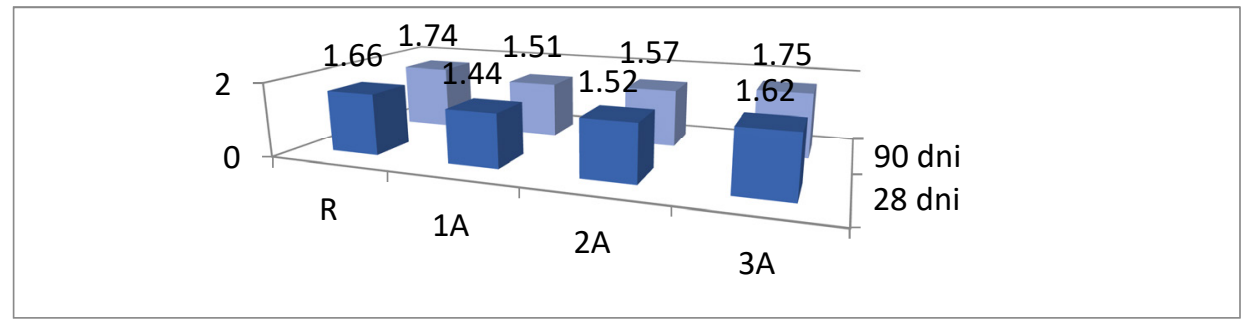

Fig. 1. Results initial tensile adhesion strenght at $10 \%$ cement replacement with fly ash: $1 \mathrm{~A}-$ ash 1 , $2 \mathrm{~A}-\operatorname{ash} 2,3 \mathrm{~A}-\operatorname{ash} 3$

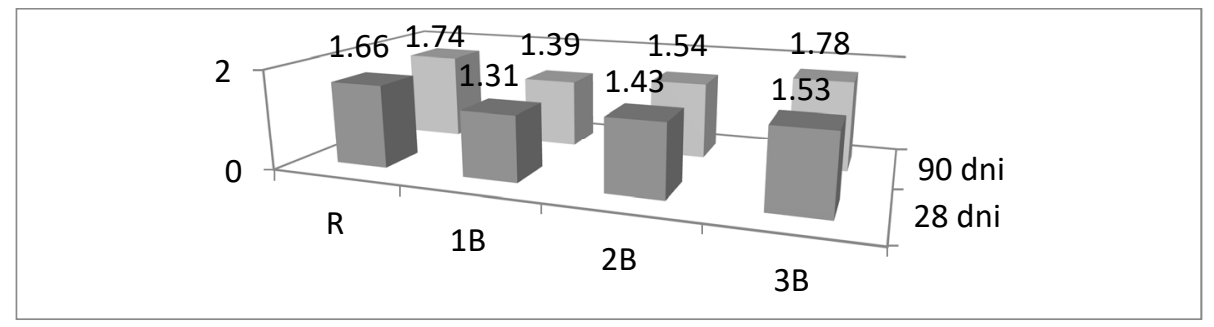

Fig. 2. Results initial tensile adhesion strenght at $20 \%$ cement replacement with fly ash: $1 \mathrm{~B}-$ ash 1 , $2 \mathrm{~B}-\operatorname{ash} 2,3 \mathrm{~B}-\operatorname{ash} 3$

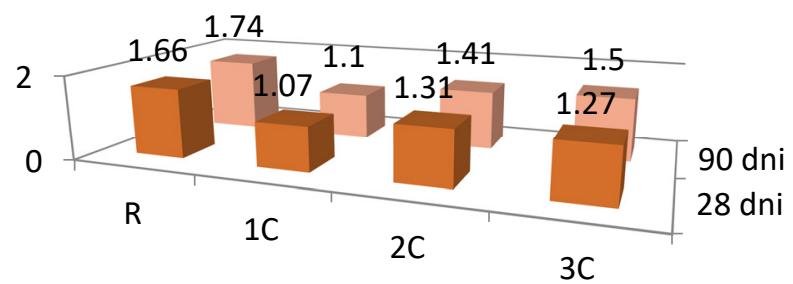

Fig. 3. Results initial tensile adhesion strenght at $25 \%$ cement replacement with fly ash: $1 \mathrm{C}-$ ash 1 , $2 \mathrm{C}-$ ash $2,3 \mathrm{C}-$ ash 3

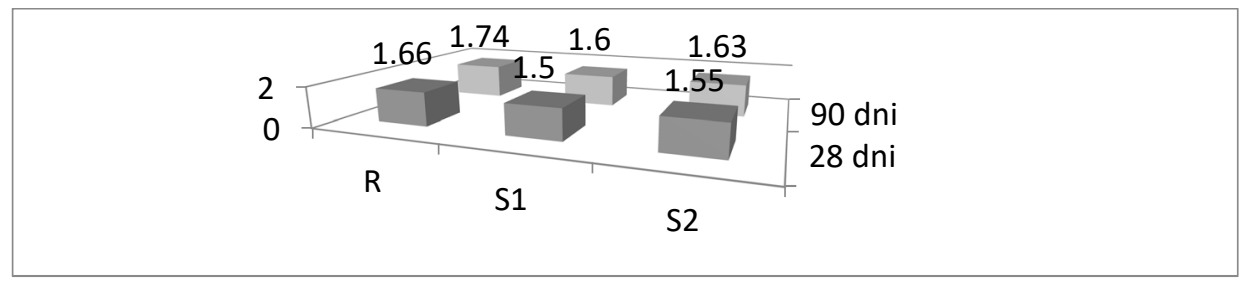

Fig. 4. Results initial tensile adhesion strenght at $10 \%$ cement replacement with granulated blast furnace slag: S1 - slag 1, S2 - slag 2

The results obtained for adhesion after immersion in water are presented in figures 58. The substitution of cement binder with ash or slag each time resulted in a decrease in adhesion after immersion in water.

For the $10 \%$ ash admixture, the changes are within the measurement error limit and do not exceed $20 \%$.

A $20 \%$ ash admix resulted in a decrease in adhesion to the limit value of $0.5 \mathrm{MPa}$. The maximum reduction in adhesion was recorded for ash 3 - by $38 \%$. It should be underlined that all adhesives meet the standard requirements in this respect. For adhesion after immersion in water, the $25 \%$ cement substitution with ash resulted in a significant 
modification in adhesion of more than $50 \%$ and for ash 3 up to $73 \%$ of the reference value.

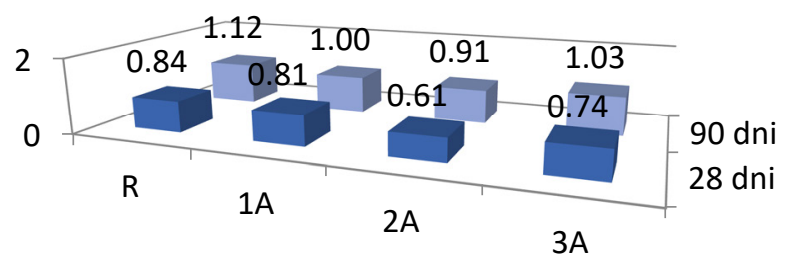

Fig. 5. Results tensile adhesion strenght after water immersion at $10 \%$ cement replacement with fly ash: $1 \mathrm{~A}$ - ash $1,2 \mathrm{~A}$ - ash $2,3 \mathrm{~A}$ - ash 3

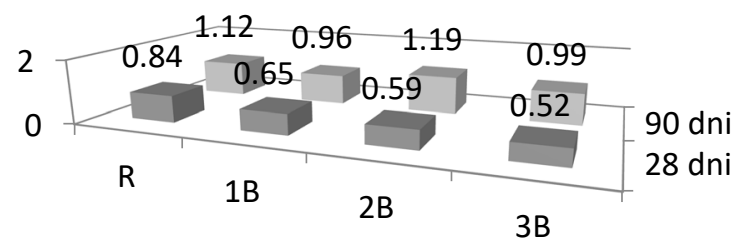

Fig. 6. Results tensile adhesion strenght after water immersion at $20 \%$ cement replacement with fly ash: $1 \mathrm{~B}$ - ash 1, 2B - ash 2, 3B - ash 3

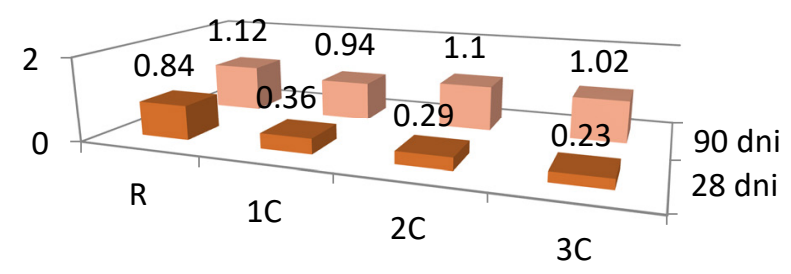

Fig. 7. Results tensile adhesion strenght after water immersion at $25 \%$ cement replacement with fly ash: $1 \mathrm{C}-$ ash $1,2 \mathrm{C}-$ ash $2,3 \mathrm{C}-$ ash 3

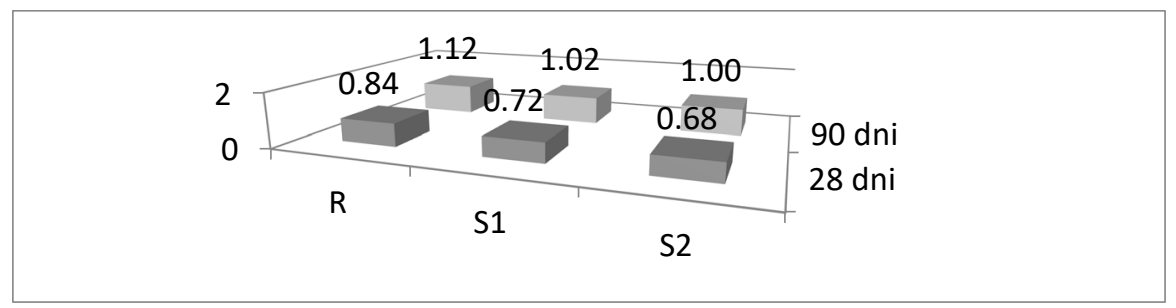

Fig. 8. Results tensile adhesion strenght after water immersion at $10 \%$ cement replacement with granulated blast furnace slag: S1 - slag 1, S2 - slag 2

The results obtained for adhesion after heat treatment are presented in Figures 9-12. The $10 \%$ cement substitution with ash 2 and 3 did not lead to any changes in adhesion when compared with the reference adhesive. For ash 1, the adhesion decreased by $18.8 \%$ from the basic value. The addition of ash 1 in the amount of $20 \%$ and $25 \%$ reduced the adhesion of adhesive to $70 \%$. 
All the adhesives after heat treatment have an initial adhesion of $\geq 1.0 \mathrm{MPa}$, allowing the basic standard requirement of $\geq 0.5 \mathrm{MPa}$, i.e. for mortars with enhanced strength parameters, to be met by a margin.

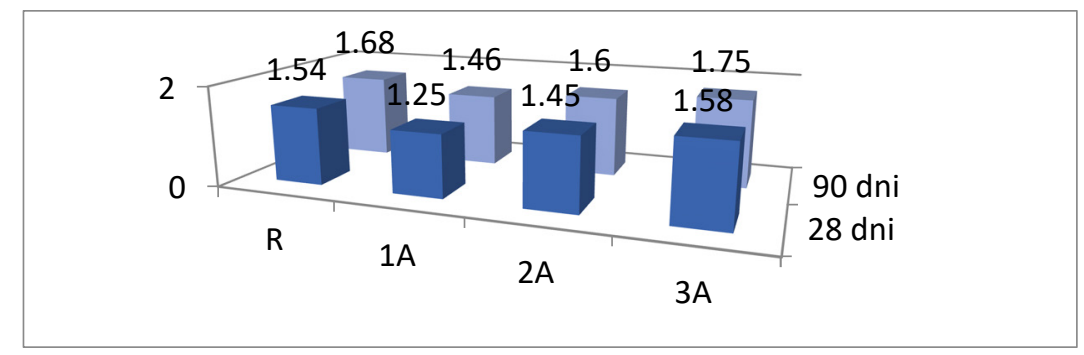

Fig. 9. Results tensile adhesion strenght after heat ageing at $10 \%$ cement replacement with fly ash: $1 \mathrm{~A}$ - ash $1,2 \mathrm{~A}-\operatorname{ash} 2,3 \mathrm{~A}-$ ash 3

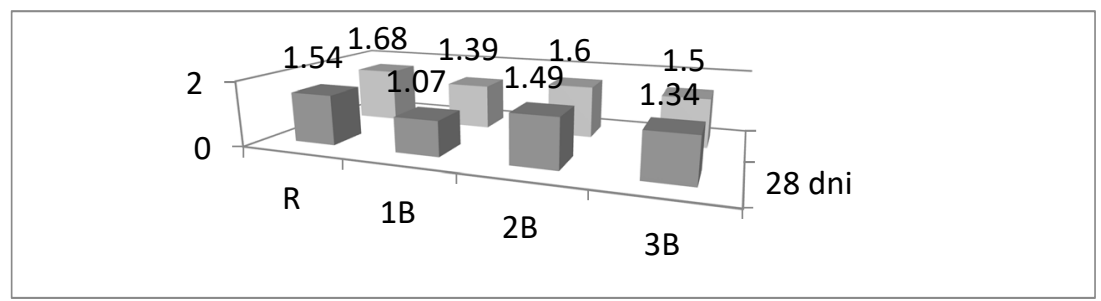

Fig. 10. Results tensile adhesion strenght after heat ageing at $10 \%$ cement replacement with fly ash: $1 \mathrm{~B}-\operatorname{ash} 1,2 \mathrm{~B}-\operatorname{ash} 2,3 \mathrm{~B}-\operatorname{ash} 3$

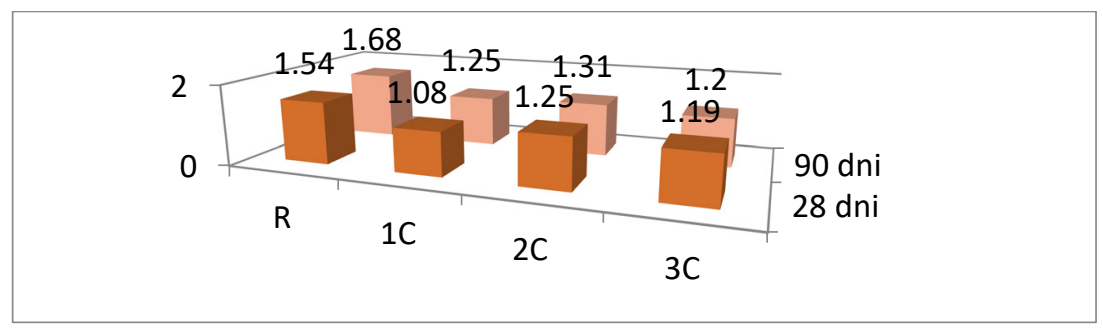

Fig. 11. Results tensile adhesion strenght after heat ageing at $10 \%$ cement replacement with fly ash: $1 \mathrm{C}-\operatorname{ash} 1,2 \mathrm{C}-\operatorname{ash} 2,3 \mathrm{C}-\operatorname{ash} 3$

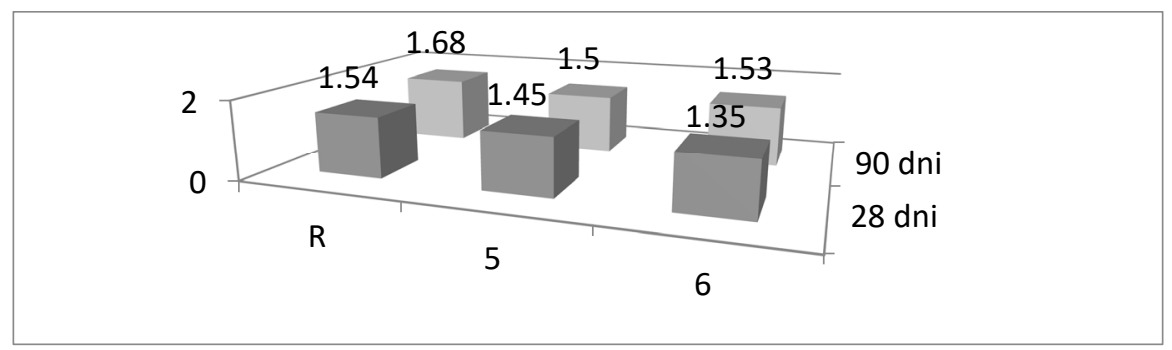

Fig. 12. Results tensile adhesion strenght after heat ageing at $10 \%$ cement replacement with granulated blast furnace slag: S1 - slag 1, S2 - slag 2

Adhesive with fly ash or granulated blast furnace slag shows a strength development that is characteristic of pozzolanic-hydraulic admixtures, a reduced early age strength and a significant increase in strength after a long hardening period. The cement substitution with ash in the case of the tested specimens generally results in a deterioration of the results of 
adhesion after 28 days. However, the differences are not significant and often fall within error limits that for values of about $1 \mathrm{MPa}$ are $0.2 \mathrm{MPa}$. For specimens conditioned for 90 days, higher values than the reference values were obtained for ash 3 .

On the one hand, the tests show an improvement in adhesion after heat treatment as well as slump performance, but on the other hand, ash admixture reduced adhesion values in case of all the remaining conditions of sample conditioning.

The results of the tests after immersion in water show dynamics of strength increase that is characteristic for pozzolanic and hydraulic admixtures: substantial strength increases after a long period of curing with relatively low early age strength.

The effect of slag addition on the properties of powder adhesives is similar as for ash. However, strength is reduced by less than it is for ash admixture.

The results of slip tests presented in Figure 13 show that $20 \%$ ash or slag admixture significantly improves the initial slip values. The most beneficial in terms of slip values is the admixture of ash 1 , which led to the reduction of the values more than three times.

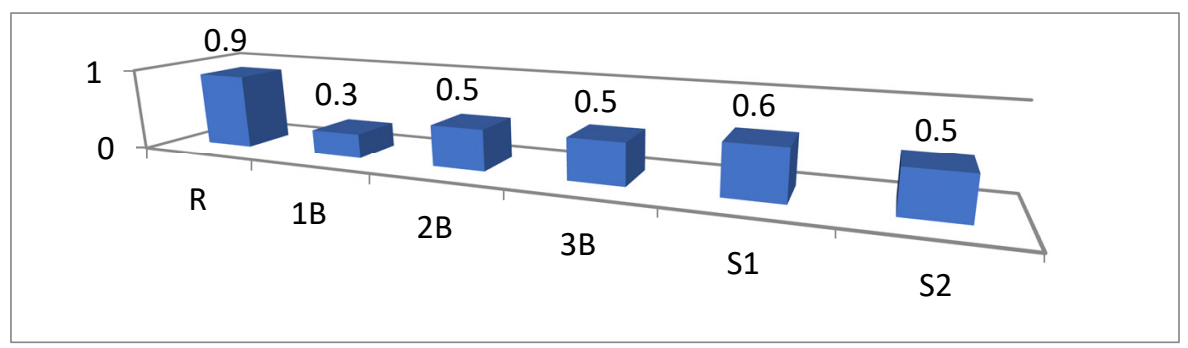

Fig. 13. Slip results at $20 \%$ cement replacement with fly ash or granulated blast furnace slag: 1B ash 1,2B - ash 2, 3B - ash 3, S1 - slag 1, S2 - slag 2

Fly ash in a concrete mixture significantly reduces its tendency to slip. This mechanism of fly ash activity is connected with the grain morphology of the vitreous phase of fly ash. Spherical shape of fly ash particles gives the mixture a better cohesion. The effect of ground granulated slag on the rheological properties of the concrete mix is, similarly to fly ash beneficial. Mortar blends with granulated blast furnace slag, introduced in the form of a type II concrete admixture, are characterized by good workability at reduced water demand.

\section{Conclusion}

- The results of tests of adhesives with ash or slag admixture differ from those obtained for the reference adhesive. The effects of admixtures vary with the level of cement substitution and the conditions of specimen conditioning. Replacement of cement with fly ash in all levels reduces the tensile adhesion strength in all conditions. The effect is more pronounced at higher substitution levels.

- Obtained results related to the properties of cements with fly ash admixture i.e. a slower increase in strength in the initial period and, at the same time, through temperature increase during curing, a significantly accelerated pozzolanic reaction and an increase in adhesive strength.

- Fly ash in a concrete mixture significantly reduces its tendency to slip. The effect of ground granulated slag on the rheological properties of the concrete mix is, similarly to fly ash beneficial. The increase in the degree of grinding and the separation of fine fractions of silica fly ash allows to improve activity rates which translate into strength properties of cement composites and thus the strength of mortars produced from them. 
Activation is mainly effective over a long period of adhesive curing and does not affect the strength after 28 days of hardening.

- The results show that an optimum cement substitution with fly ash (20\%) or granulated blast furnace slag (20\%) will allow to obtain high performance tile adhesives.

\section{References}

1. EN 12004+A1 (2012)

2. EN 197-1 (2012)

3. T. Baran, A. Garbacik, M. Ostrowski, H. Radelczuk, Konferencja Dni Betonu, Wisła 439-448 (2016)

4. S. Sladnicka, Cement Cncrete Res. 21, 241 (1991)

5. Z. Giergiczny and A. Weryńska, Proceedings Third International Conference Trondheim, 97 (Norway 1989)

6. W. Nocuń-Wczelik, Konferencja Dni Betonu, (Wisła 2004)

7. S. Diamond, Proceedings of Conference on Hydraulic Cement Pastes: their structure and properties, Sheffield Cement and Concrete Association, (1976)

8. O. Andic, K. Ramyar, O. Korkut, Constr. Build. Mater $19564-569$ (2005)

9. Z. Giergiczny, A. Garbacik, XII Sympozjum Naukowo-Techniczne „Cement wtaściwości i zastosowanie”, 5-23 (Gliwice 2010)

10. J. Kuteraśińska, A. Król, Economic and Environmental Studies 16 (3), 403-419 (2016)

11. EN 450-1 (2012)

12. $\mathrm{PN}-85 / \mathrm{B}-04500$

13. EN 1348 (2008)

14. PN-EN 1308 (2008) 